\title{
Genesis of the Definition "Goodwill" as Economical Category: International and Russian Aspect
}

\author{
O.A. Kuzmenko ${ }^{1}$ and A.M. Dyachkova-Politi ${ }^{1, *}$ \\ *Corresponding author: amdacett@yahoo.com \\ ${ }^{1}$ Tyumen State University, Tyumen, Russia
}

\begin{abstract}
The article is devoted to formation of the definition "Goodwill" in Russian accounting practice based on historical trends, regulations and standards. During the research the definition was explored from legal stand point, were considered major milestones in its development and, as a result, it was concluded that further development will be necessary due to acceptance of the International Financial Reporting Standards on territory of Russian Federation. It compares experience of the United States and Russia in regulation of the definition and its realization and recognition in financial reporting. As an economic category goodwill have gone through development of the definition reputation to the leading indicator of the company's stability in merger and acquisition process. From this position, usage of goodwill in consolidated financial reporting is crucial and requires development of the mechanisms for implementation and guardianship of the intangible assets, its proper amortization and impairment.
\end{abstract}

Keywords: Goodwill, business reputation, intangible assets, accounting, financial reporting, international aspect.

\section{Introduction}

In modern conditions of Global market relationships we quite often can meet forms of business which are combined and consolidated. Due to the quickly developing technologies and growth of the distribution markets, combined organizations expand their interests via mergers with new companies in different forms. In this case especially important become formations of the consolidated reporting.

\section{Problem Statement}

The goal of this research is to identify general aspects in defining the goodwill in mergers and its presentation in reporting based on current Russian and international regulations. While the regulations are still in its development stage there are some differences based on the country and the size of the consolidated companies.

Chosen for the research topic is widely discussed and interested for Russian accounting society. As it has been noticed, formation of the standards of the modern accounting most of the time comes from practice and necessities of the ways the business is conducted. Even quickly changing regulations not always respond to the questions that are solved in practice. Quite often resolution of such questions in practice is based on the innovative methodologies and practical developments with account to the specifics of the company or field.

Modern Russian accounting tends to consider, adopt and introduce international practice. In this case, development of theoretical and legal basis for correct recognition and reflection of the finance and economic operations is necessary. Essential theoretical work of the topic is presented in educational and methodical materials which consider general positions of the international standards for financial reporting (IFRS).

\section{Research Questions}

The main research question is to identify and define the basis of recognition for goodwill in consolidated financial reporting based on experience of two countries, Russia and the USA. Consideration of development of goodwill as an economical category and its evolution throughout different accounting regulations and basic requirement for the economic element are to be recognized in financial reporting. Thereby gathering of such experience will give us basis to make conclusions about the usage of this category in financial analysis and practicality of its usage in financial reporting in general.

\section{Purpose of the Study}

The purpose of this study is to emphasise the importance of goodwill as economic category and its recognition in financial reporting, explorer problems of its identification and regulation. Goodwill is a guarantee of stability and 
positive synergy of the company to generate positive cash flow. Article offers to consider international experience of accounting treatment of the definition and summarizes it with the emphases fundamental components of goodwill and its types.

\section{Research Methods}

Methodology of the conducted research is not limited to one or two techniques, but is performed with the complex of methods. During the study integral role is played by the interpretation of the information of about business entity as a whole, performed observation of the changes of social-economical connections, methods of gathering, interpretation and analysis of the information, reasoning of the selections are related to the particular events and within the topic of the study. The sources of the information involved into the study include but are not limited to Russian Federation regulations in accounting field, The United States accounting standards, international standards accepted on the territory of Russian Federation.

\section{Findings}

Historically the term goodwill is not used in Russia. Even FZ N 402-FZ «About accounting» or N 208-FZ "About consolidated financial reporting", where the object of accounting is named as an entity, there is no reference to this term $[1,2]$. Among the factors of the business relationship are "deals influencing financial position of the entity, financial results of its activity and cash flow" (article 3, part 8) [2]. Thus, deals of purchase of the company or its part are a fact of the entities economical activity and have to be accounted for. Special attention we should pay to the company's opportunity to form its own accounting policies, it allows company to bring in new line items, including goodwill (article 8, part 2) [2].

Literature review on business valuation topic have shown that just a few fundamental publication were devoted to it. Special attention was paid to the article written by S.A. Kuzubov [3], which has a description of the history of the definition and goodwill as part of business. Another work is devoted to the history of the definition as well as different methods of it accounting and presentation in reporting [4].

Few other interesting articles were written by the American economists and researchers in accounting field, these articles are based on statistical data. Among those authors are S.L. Henning et al. [5-7], L.T. Johnson \& K.R. Petrone [8]. These researchers have explored the definitions goodwill, its components, relationship and changes of economic indicators based on goodwill. Among modern Russian periodic publications we should emphasis work of V.I. Kolosova and T.Y. Vavilicheva who have researched legal side of the definition goodwill in terms of civil and criminal law [9].

The constrain in application of the international consolidation practice is the absents of the tax regulation in Russia which would of recognize goodwill. According to Russian tax code such position would artificially increase value of capital and lower financial results. Thus, research of the international practice in goodwill treatment and its economic influence on company's financial position is very important for current development of Russian accounting and tax practice.

Goodwill is a result of the investors wish to receive income from the companies they invest into. One of the goodwill definitions given centuries back concludes that "Goodwill as asset represents advantage, arisen based on possibility that clients will be visiting the business often, that it depends on the firm's reputation; goodwill includes advantage given to the owner to be presented as is; and that the value of the business depends on the business connections; goodwill received during the purchase of the business includes right to use these connections" [10]. The author highlights that demand to the definition of goodwill have arisen with the growth and development of stock companies in the beginning of XX century. This caused the need and influenced recognition of goodwill in financial reporting. British company's act of 1900 required each prospect to announce the price of goodwill separately if it should have been required to acquire it from the price paid for the acquisition of stock subscription.

Formation of the goodwill definition was happening in parallel to the property rights. While studying historical experience, it worth to point that in the USA in 1917 for the first time legally was allowed during the acquisition of the company to pay for stock without full amount for its price. Thus, companies had to account for the difference between market price of the stock and amount paid for goodwill. Despite of differences in defining goodwill, this term is at the center of accounting discussions since 1874 .

For Russia enactment of the International declaration of human right has become a pivotal point in formation of goodwill definition. Considering that in Russian the course of harmonization of accounting standards with the international is taken place, some changes in this direction were made and will continue to happen. Starting from 2007 business reputation became an intangible asset, recognized as a result of the company's purchase and should be amortized within 20 year period [11]. Goodwill as economical category is starting to be accepted by the accountants in Russia. Modern definitions explain this economic category as a difference between prices paid for excessive income (excessive income is a difference between income of the acquired assets and normal income received form a similar asset). Thus, we can see connection between goodwill and income of the company [12]. 
IFRS 3 stated that implementation of the accounting principles in acquisition can lead to recognition of some assets and liabilities which were not recognized before in financial reporting [13]. Examples of such assets could be acquired and earlier not recognized name of the brand, patents and client relationship. Thus, those are the assets which were created and developed internally before the acquisition deal and were expensed in financial reporting prior (part 32). Out of the definition from the International standard we can conclude that company usually cost more than its real value. There is no definition of goodwill in Russian regulations. However, there is a term business reputation used in regulations without its clearly expressed definition. Therefore, business reputation is very similar to goodwill and defined as excess of the company's cost based on its ability to generate higher profit due to the efficient management system and usage of new technologies.

However we should always remember that in accordance with the international standards business reputation is one of the parts of goodwill. In Article 152 of the Civil Code of Russian Federation (further CC RF) mentions business reputation but does not define for purposes of accounting system [14]. There is an opinion that recognition of goodwill will require adjustments in definition of reputation, development of definition for goodwill and admission of it as a part of property relationship and clearly identify the consistence of goodwill as intangible asset. In accordance with the articles 1027-1040 CC RF, business reputation can be transferred from one party to another based on agreement during the period identified by this agreement and can be part of the investment article 1042 (par.1,2) CC RF [14].

In Russia we still have valid national standards which assume business reputation in accounting in purchase of the company, existence of the positive and negative business reputation and its amortization within 20 years period [11]. In accordance with №208-FZ consolidated reporting should be prepared based on rule of IFRS (part 3, subpart 1). It means that goodwill should be accounted for in accordance with the international rules as well [13].

Currently Order of RusStat 31.05.2018 N 334 "About approval of official statistical methodology to build the balance of assets and liabilities and accounts for gathering national information about contracts, rental agreements, licenses, goodwill and marketing assets" has enacted form 11-HA, which requires business entities present information to the statistics governmental body [15]. Such reports should be presented not later than $30^{\text {th }}$ of June each year following the reporting year. In this case the statistics entities will be gathering such information annually including all the renewed agreements and newly signed. Such statistical form will give government access to the internal corporate information, including the amounts of the contracts licenses to perform certain type of activities. Accountability of this sort brings intangible assets to strong regulation.

Goodwill can be divide into three types: first related to business - institutional, second professional and third personal [16]. Each category differs by the origin of the source of goodwill. Such differentiation does not influence its evaluation. First category covers institutional goodwill, which included by the commercial and industrial companies. Second type includes two components: human and entity. The first component is based on skills, education, reputation, practice of the professional. Business component covers all the things related to it: its location, reputation, longevity, production assets, operational procedures. The most controversial in valuation of goodwill is to identify who owns and what part. Such question quite often appears when during the legal procedures between the spouses, between the stock holders and etc. Professionals of the accounting and financial reporting field sometimes evaluate the components separately. The last type of goodwill, personal, is related to the celebrities, such as sportsman, movie stars. Such goodwill is being evaluated based on the skills and abilities of the people who hold it. As it could be noticed transfer of such goodwill could be difficult due to inseparability of it from the barer.

In order to identify if goodwill is related to the company or can be valued separately few factors should be considered: 1) If the person makes all the decisions related to business, 2) functioning of the business is inseparable from the person, 3) success of the company is directly related to the specific person. As it was identified, during development of the company, especially movement form the middle size company to a bigger one, shift in goodwill can be observed from personal goodwill to professional goodwill [16].

In order to understand the importance of goodwill we should learn the history of the international practice and standards regulating recognition and reporting of this economic category. History of American practice has pointed out three main methods of handling goodwill. The first one prescribes that goodwill should be expensed immediately, as any other expenses of the company from the company's income. Next method places goodwill as a regular asset of the company and amortize it over period of its usage (ARB 17 - 40 years), the amortized amounts should be allocated to the period when the benefit was received. Previous American standards regulated accounting practice relied on this position. These standards (Accounting Principles Board (APB) Opinion No.16, 17) required to use linear method of amortization during 40 year period [17-19]. The last method of goodwill treatment assumes that it is recognized during the M\&A deal and capitalized with testing for impairment in the periods after the deal. Internal goodwill in this case is written off as expense immediately.

One of the fundamental researches about goodwill was written by representatives of FASB T.L. Johnson and K.R. Petrone in 1998 [8]. FASB considered possibility of recognition of goodwill in accounting practice as asset. Performed research was conducted during development of the new American standard for business combinations. At that time it was acceptable to recognize goodwill in M\&A deals and amortize it after it within 40 years but really was not clearly upholding this regulation. In practice most of the companies were not recognizing goodwill and were not amortizing it. This question was not only crucial but had a political implication as well because a percentage from the acquisition price assigned to goodwill is relatively high and was influencing tax basis. While considering the concept of goodwill FASB came to an opinion that goodwill is an asset because it has all major characteristics of the asset. 
Considered methods to identify goodwill were emphasized including the fact that it is inseparable from the asset and related to the expectations of the potential buyer to receive benefit from the asset after the conclusion of the deal. Secondly, the components of goodwill are identifiable and do have value for the purchaser. As it was offered by one of the American standards, goodwill should have been calculated as a residual value of the asset. Three main types of components include: continuation of the business, synergy and residual. Each of these components is important for successful business operations and its stability. Components necessary for continuity of business are based on the ability of the assets to produce higher income then these assets would produce separately. Components of synergy are generated and unique for each company such as corporate culture, spirit of the company, team building. Residual components are accounted for as a result of mistakes in valuation of assets, reevaluation, and undervaluation and via presents of unrecognized assets. Such components often included into goodwill, but in reality they do not have any reason behind to be recognized in any fashion as assets. Core of goodwill includes three general characteristics of asset as category. It generates future economic effect received as a result of past events and is controlled by the acquiring company. As it was notices in this research, the fact that it is generating economic benefit, the asset cannot be exchanged separately or used as a payment for liabilities. Indirect income and less certain economical benefits are often discussed by the professionals in accounting field.

When we talk about goodwill as economic category we should remember about structure and basics of accounting principles. Goodwill with regards to its origin follows to the basic principle for the line item being recognized in the reporting just partially. Thus, in accordance to IAS 38 internally developed goodwill is not recognized as an asset (part 48) [20], even if it does follow the principle of recognition. For example, expenses for development of the company are related to the current expenses and recognized in profit and loss statement (income statement) without influence to creation of the additional goodwill. Goodwill is not appearing during the signing of the contract or implementation of the legal obligations, is not controlled by the company and cannot be measured by the purchase price. In agreement with IFRS and GAAP goodwill is a special category which is not amortized but tested regularly (annually) for impairment.

In American practice goodwill is accounted and presented in accordance with ASC 350 Intangibles - Goodwill and Other [21]. Comparing with Russian accounting practice American regulatory practice historically use goodwill as integral part of the balance sheet in operations of merger and acquisition. Starting from July 2001 SFAS No. 142 and 141 were enacted and all acquisitions (mergers and acquisitions deals) were supposed to be accounted as purchase and goodwill should be recognized as part of the price [21-24]

\section{Conclusion}

Advanced study of practical and economical side of goodwill will allow us to identify possible ways to recognize and report goodwill in financial documents. In further publications we will perform analysis of the practice based on actual financial reporting.

\section{References}

1. Federal Law from 27.07.2010 N 208-FZ "About consolidated financial reporting". Retrieved from: http://www.consultant.ru/document/cons_doc_LAW_103021/. Accessed: 09.12.2018 (2010). [in Rus.].

2. Federal Law from 06.12.2011 N 402-FZ "About accounting" Retrieved from: http://www.consultant.ru/cons/cgi/online.cgi?req=doc\&base=LAW\&n= 286976\&fld=134\&dst=1000000001,0\&rnd=0.40318588521292553\#0051993306572414744. Accessed: 04.12 .2018 (2011). [in Rus.].

3. S.A. Kuzubov, Goodwill is an object for accounting: Sources of origin. Branches of Law. URL: http://xn---7sbbaj7auwnffhk.xn--p1ai/article/2722 (2015). [in Rus.].

4. L. Feleaga, N. Feleaga, V.D. Dragomir, Accounting for goodwill: A historical review. European Journal of Management, 11(1). Retrieved from URL: https://pingpdf.com/pdf-accounting-for-goodwill-a-historical-reviewfreepatentsonline.html (2011).

5. S.L. Henning, B.L. Lewis, W.H. Shaw, Valuation of the components of purchased goodwill. Journal of Accounting Research, 38(2), 375-386. DOI: 10.2307/2672938 (2000).

6. S.L. Henning, W.H. Shaw, The effect of the tax deductibility of goodwill on purchase price allocations. The Journal of the American Taxation Association: Spring 2000, 22(1), 18-37. DOI: 10.2308/jata.2000.22.1.18 (2000).

7. S.L. Henning, W.H. Shaw, Is the selection of the amortization period for goodwill a strategic choice? Review of Quantitative Finance and Accounting, 20(4), 315-333. DOI: 10.1023/A:1024043316292 (2003).

8. L.T. Johnson, K.R. Petrone, Is goodwill an asset? Accounting Horizons, 12(3), 293-303 (1998).

9. V.I. Kolosova, T.Y. Vavilicheva, Business reputation: Definition, problems of legal regulation and security. Journal of Nigegorodskii University N.I. Lobachevskogo, 3(1), 258-266. URL: http://www.unn.ru/pages/issues/vestnik/99999999_West_2011_3/45.pdf (2011). [in Rus.].

10. M. Glaum, W.R. Landsman, S. Wyrwa, Determinants of goodwill impairment under IFRS: International evidence. Vallendar, Germany: SSRN. Retrieved from 
URL:https://www.business.uq.edu.au/sites/default/files/events/files/glaum_landsman_wyrwa_goodwill_impairment 1 _march uq.pdf (2015).

11. Prikaz Minfina Rossii ot 27.12.2007 N 153n "Ob utvergdenii Poligenia po buhgalterskomu uchetu "Uchet nematerialnih activov" (PBU 14/2007)" Retrieved http://www.consultant.ru/document/cons_doc_LAW_63465/. Accessed: 09.12.2018 (2007). [in Rus.].

12. Y. Jahmani, W.A. Dowling, P.D Torres, Goodwill impairment: A new window for earnings management? Journal of Business and Economics Research, 8(2), 19-24 (2010).

13. International Financial Reporting Standard (IFRS) 3 "Business combinations" attachment N 31. Order of the Ministry of Finance of Russian Federation from 28.12.2015 N 217n. Retrieved from: http://www.consultant.ru/document/cons_doc_LAW_124548/. Accessed: 19.12.2018 (2015). [in Rus.].

14. Civil Code of the Russian Federation from 30.11.1994 N 51-FZ. Retrieved from: http://www.consultant.ru/document/cons_doc_LAW_5142/. Accessed: 09.12.2018 (1994). [in Rus.].

15. Order of RusStat from 31.05.2018 N 334 "About approval of official statistical methodology to build the balance of assets and liabilities and accounts for gathering national information about contracts, rental agreements, licenses, goodwill and marketing assets" Retrieved from: http://www.consultant.ru/document/cons_doc_LAW_299325/. Accessed: 09.12.2018 (2018). [in Rus.].

16. R.F. Reilly, Goodwill valuation approaches, methods, and procedures. Financial Advisory Services Insights. URL: http://www.willamette.com/insights_journal/15/spring_2015_2.pdf (2015).

17. American Institute of Certified Public Accountants. Accounting Principles Board, Business combinations. Opinions of the Accounting Principles Board 16 APB Opinion 16. Retrieved from: http://clio.lib.olemiss.edu/cdm/ref/collection/aicpa/id/272. Accessed: 04.12 .2018 (1970).

18. American Institute of Certified Public Accountants. Accounting Principles Board, Intangible assets. Opinions of the Accounting Principles Board 17 APB Opinion 17. Retrieved from: http://clio.lib.olemiss.edu/cdm/ref/collection/aicpa/id/322. Accessed: 04.12.2018 (1970).

19. American Institute of Certified Public Accountants. Committee on Accounting Procedure, Accounting for Intangible Assets. Accounting Research Bulletin, no. 24 (ARB 24). Retrieved from: http://clio.lib.olemiss.edu/cdm/ref/collection/deloitte/id/9502. Accessed: 21.01 .2019 (1944).

20. International accounting Standard (IAS) 38 "Intangible assets" (Order of the of the Ministry of Finance of Russian Federation from 28.12 .2015 N 217n). Retrieved http://www.consultant.ru/document/cons_doc_LAW_193595/. Accessed: 09.12.2018 (2015). [in Rus.].

21. Financial Accounting Standards Board of the Financial Accounting Foundation Intangibles - Goodwill and Other (Topic 350). Retrieved from: https://www.fasb.org/cs/BlobServer?blobkey=id\&blobwhere=1175822937733\&blobheader=application\%2Fpdf\&bl obcol=urldata\&blobtable=MungoBlobs. Accessed: 21.01 .2019 (2011).

22. R.F. Reilly, SFAS Nos. 141 and 142 Implications for Goodwill Acquired by M\&A. American Bankruptcy Institute Journal, (Feb. issue). Retrieved from: https://www.abi.org/abi-journal/sfas-nos-141-and-142-implications-forgoodwill-acquired-by-ma (2006).

23. Financial Accounting Standards Board of the Financial Accounting Foundation, Statement of Financial Accounting Standards No. $141 \quad$ "Business Combinations". Retrieved from: https://www.fasb.org/jsp/FASB/Document_C/DocumentPage?cid=1218220124901\&acceptedDisclaimer=true. Accessed: 04.12.2018 (2001).

24. Financial Accounting Standards Board of the Financial Accounting Foundation, Statement of Financial Accounting Standards No. 142 "Goodwill and Other Intangible Assets". Retrieved from: https://www.fasb.org/jsp/FASB/Document_C/DocumentPage?cid=1218220124961\&acceptedDisclaimer=true. Accessed: 04.12.2018 (2001). 